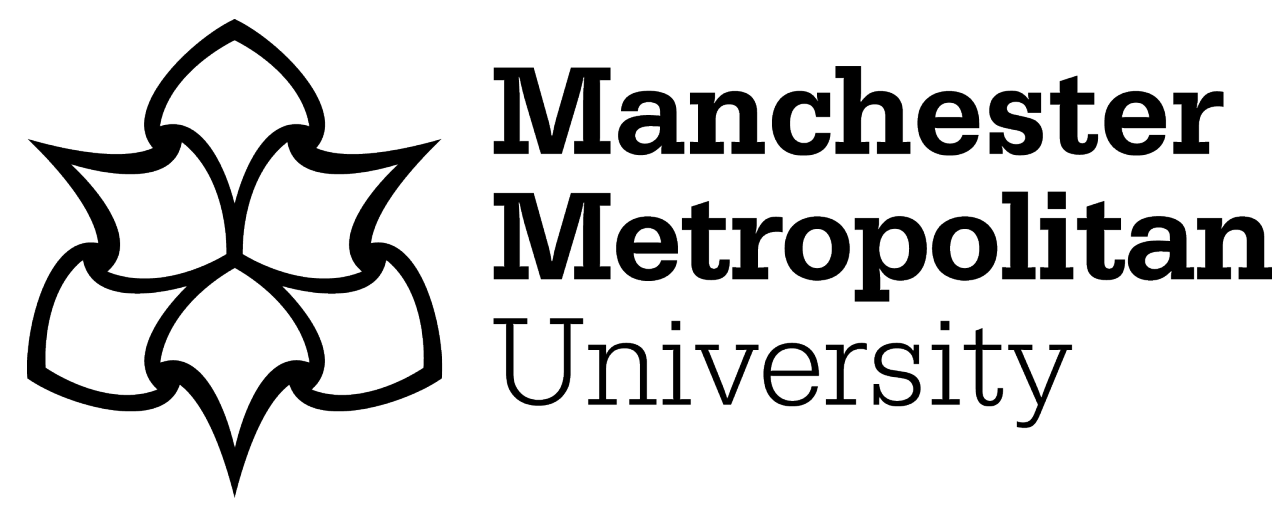

Lai, Yanqing ORCID logoORCID: https://orcid.org/0000-0001-9107-3464, Saridakis, George and Blackburn, Robert (2013) Job Stress in the United Kingdom: Are Small and Medium-Sized Enterprises and Large Enterprises Different? Stress and Health, 31 (3). pp. 222-235. ISSN 1532-3005

Downloaded from: https://e-space.mmu.ac.uk/623803/

Version: Accepted Version

Publisher: Wiley

DOI: https://doi.org/10.1002/smi.2549

Please cite the published version 
RESEARCH ARTICLE

\title{
Job Stress in the United Kingdom: Are Small and Medium- Sized Enterprises and Large Enterprises Different?
}

\author{
Yanqing Lai ${ }^{*}$, George Saridakis \& Robert Blackburn \\ Small Business Research Centre, Kingston Business School, Kingston University, Surrey, United Kingdom
}

\begin{abstract}
This paper examines the relationships between firm size and employees' experience of work stress. We used a matched employer-employee dataset (Workplace Employment Relations Survey 2011) that comprises of 7182 employees from 1210 private organizations in the United Kingdom. Initially, we find that employees in small and medium-sized enterprises experience lower level of overall job stress than those in large enterprises, although the effect disappears when we control for individual and organizational characteristics in the model. We also find that quantitative work overload, job insecurity and poor promotion opportunities, good work relationships and poor communication are strongly associated with job stress in the small and medium-sized enterprises, whereas qualitative work overload, poor job autonomy and employee engagements are more related with larger enterprises. Hence, our estimates show that the association and magnitude of estimated effects differ significantly by enterprise size. Copyright (c) 2013 John Wiley \& Sons, Ltd.
\end{abstract}

Received 22 May 2013; Revised 27 August 2013; Accepted 4 October 2013

Keywords

SMEs; work stress; job stressors; enterprise size

*Correspondence

Yanqing Lai, Small Business Research Centre, Kingston Business School, Kingston University, Kingston Hill, Kingston Upon Thames, Surrey, KT2 7LB, United Kingdom.

†Email: k1250665@kingston.ac.uk

Published online 3 December 2013 in Wiley Online Library (wileyonlinelibrary.com) DOI: 10.1002/smi.2549

\section{Introduction}

Work stress has been increasing in the United Kingdom since 1992, measured at an annual rate of $0.5-1.0 \%$ (Chandola, 2010). According to the research commissioned by Health and Safety Executive (2007), stressrelated issues cost the UK economy $\mathfrak{E} 530 \mathrm{~m}$, and more than half of a million employees have work stressrelated health problems. A large volume of research has been carried out to explore the nature, antecedents and outcomes of job stress by exploring the relationship between the stimulus surrounding the job and work environment and the responses of employees (e.g. Beehr, Jex, Stacy, \& Murray, 2000; Cooper, Kirkcaldy, \& Brown, 1994; Logan \& Ganster, 2005; Nakao, 2010). According to Cooper and Marshall (1976), the potential sources of stress or job stressors can be manifested in five primary categories, including intrinsic to job, role in organization, career development, work relationship and organizational structure and climate. These stressful working environment and conditions are considered as risk factors resulting in employees' physical and psychological problems as well as negative behavioural outcomes, such as physically unhealthy (Xu, Zhao, Guo, Guo, \& Gao, 2009), negative health and lifestyle behaviours such as smoking (Noblet \& Lamontagne, 2006), lower job performance (Ton \& Huckman, 2008), negative employee attitudes and subsequent withdrawal behaviours (Ahsan, Abdullah, Fie, \& Alam, 2009; Michael, Court, \& Petal, 2009).

Empirical studies undertaken to date tend to focus on the micro-level analysis, with particular interest in so-called high-risk occupations, e.g. nursing, teachers and police officers (e.g. Chan, Lai, Ko, \& Boey, 2000; Dyer \& Quine, 1998; Johnson et al., 2005). Little work has been conducted, however, at a macro level, on small and medium-sized enterprises (SMEs) and large enterprises. Man, Lau, and Chan (2001) argue that small business enterprises are distinctive from large enterprises, in terms of organizational structure, responses to external social environment, job nature and working environment. These structural and contextual characteristics are closely linked to work experience and subsequently mirrored in various job stressors under Cooper and Marshall's model of job stress (1976). Hence, we expect that employees' experiences of stress in the small enterprises will be qualitatively varied from their counterparts in the large enterprises 
(Jackson, Schuler, \& Rivero, 1989), and the difference should be reflected in various job stressors.

The purpose of this paper is to examine whether the impact of various stressful aspects of job on employees' experience of overall job stress differ significantly by enterprise size. We use a matched employer-employee dataset from the latest wave of Workplace Employment Relations Survey (WERS2011) in the United Kingdom to address these issues and to contribute to the literature on stress in the workplace. The remaining paper is organized as follows. The next section discusses the role of enterprise size in several major types of stressors (e.g. job insecurity, work overload, work relationship, organizational structure and work environment) and their potential impact on employees' experience of job stress by enterprise size. The discussion is followed by a detailed description of dataset and methods used to test the hypotheses and the in-depth analysis of the results. The conclusion and implications are discussed in the final section.

\section{Background and hypothesis derivation}

Cooper and Marshall's (1976) model of job stress (Figure 1), developed on the theory of personenvironment fit, ${ }^{1}$ has been widely recognized and adopted in many empirical studies (e.g. Chan et al., 2000; Johnson et al., 2005; Nakao, 2010). In this paper, we focus on the four major types of job stressors, including work overload, poor career aspects (job insecurity and promotion), positive work relationship, organizational structure and environment (the extent of job autonomy, the level of employees' engagement at work and degree of effective communication). Arguably, job stress is caused by stressors derived from the nature of the job or/and the social and work environment where the job is performed, which is initially in the determination of basic organizational characteristics. Jackson et al. (1989) suggest that size predicts these characteristics and may act as a potential marker variable for various facets of work experience (Dekker \& Barling, 1995).

Work overload occurs when the amount of time and resources available to an individual cannot comply with the role requirement (Cartwright \& Cooper, 2002; Rizzo, House, \& Lirtzman, 1970) and it can be understood from quantitative and qualitative perspective (French \& Caplan, 1973). Quantitative overload refers that an individual has 'too much to do', whereas qualitative overload means that the job is 'too difficult to do'. People experience work overload if they are assigned an excessive amount of work or the work is

\footnotetext{
${ }^{1} \mathrm{~A}$ high level of person-environment fit suggests that a person's, knowledge, skills and abilities match the demands and requirements of the job, or the resources needed by the person to perform the job are available in the organization.
}

beyond their skills and capabilities. Employees that suffer from work overload are reluctant to go to work because they do not feel that they have enough energy, time and effort to complete their tasks (Ahsan et al., 2009). Work overload has been associated with a number of issues such as anxiety, job burnout, attention and concentration problems and work accidents (Glisson, Dukes, \& Green, 2006; Kahn \& Byosiere, 1992), as well as some withdrawal behaviours such as absenteeism and increasing employee turnover (Jamal, 1990; Rahim, 1992; Rainnie, 1989). Many researchers (e.g. Vakola \& Nikolaou, 2005; Wilkes et al., 1998) report that work overload and time constraints are significant contributors to work stress.

Kotey (1999) and Buultjens and Orme (2002) argue that small enterprises tend to be labour intensive, and therefore, the jobs typically contain various work roles and are less narrowly defined (Bacon, Ackers, Storey, \& Coates, 1996; Carroll, Marchington, Earnshaw, \& Taylor, 1999). Employees in small enterprises are more likely to be placed in overload situations and required to act as generalists working on multiple roles and tasks. Work overload, in the form of work overtime, is viewed as the most conventional way for small firms to achieve internal numerical flexibility (Kok et al., 2011). Asking employees to work outside normal working hours is an efficient practice to react quickly to temporary workload peaks. In contrast, large enterprises with greater financial and human resources can divide various tasks and activities across different specialist departments, and individuals are given a clear job specifications and concentrate on using particular skill sets and resources to perform their role. Hence, we derive our first hypothesis

Hypothesis 1: Work overload increases employees' experience of work stress, and the association is likely to be stronger for SMEs than for large enterprises.

Job insecurity is defined as an overall concern of losing a job or discontinuation of the job (Coetzee \& De Villiers, 2010), implying a significant level of uncertainty about one's employment status in the future. Nelson and Burke (2000) suggest that employees are more likely to experience job stress if they feel that their career development and achievement are threatened. Storey, Saridakis, Sen-Gupta, Edwards, and Blackburn (2010) suggest that small enterprises primarily face external uncertainty and lack the market power to influence prices and control the external environment, leading to considerably more financial fragility and instability than large enterprises (Clarke, 2011). Therefore, small enterprises are more viable to cease trading than large enterprises, leading to job loss. In addition, small enterprises offer lower levels of formal training, limited career paths and less protection against dismissals that can threaten employee's career prospects compared with larger organizations (Burgess, 1992; Urwin, Karuk, Buscha, \& Siara, 2008; Wagner, 1996). 


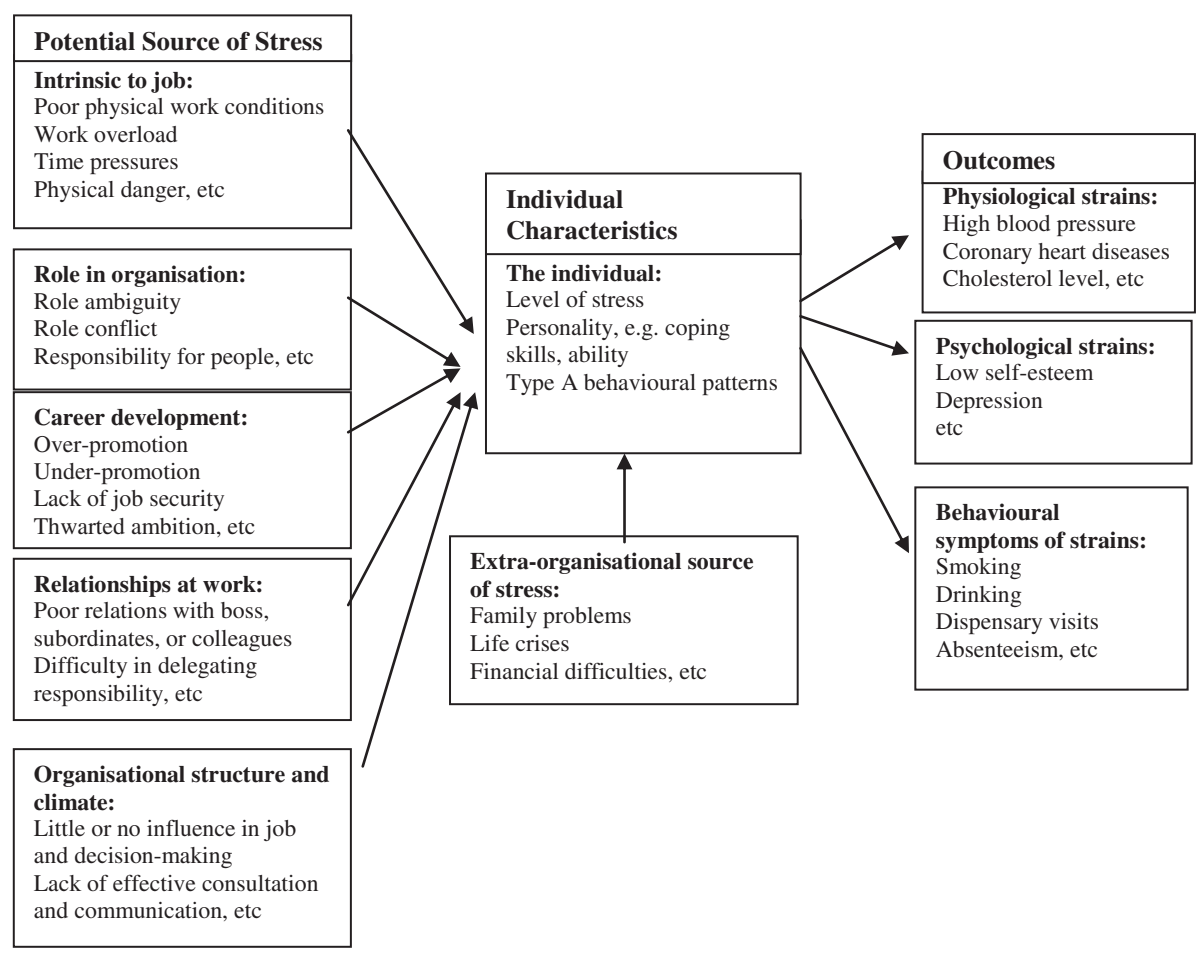

Figure 1. A model of stress at work (adopted from Cooper \& Marshall, 1976)

Some studies have shown that employees working for small enterprises prefer to work in large enterprises for greater job security and better terms and conditions (Idson, 1996; Idson \& Oi, 1999; Marlow \& Patton, 2002). Therefore, our second hypothesis suggests that

Hypothesis 2: Poor career prospects increase employees' experience of work stress, and the effect is likely to be stronger for SMEs than for large enterprises.

Work relationships between members of a work unit or a group are vital to employees' and organizational health (e.g. Argyris, 1964; Cooper, 1973; Vakola \& Nikolaou, 2005; Leka, Griffiths, \& Cox, 2004). According to French and Caplan (1973), a good relationship can be characterized as a high level of mutual trust and supports among co-workers and between employees and managers. The latter involves coaching, providing protection, giving challenging assignments, increasing the visibility of employees, giving direct forms of sponsorship and/or psychosocial support by acting as a role model, friend and counsellor (Dreher \& Ash, 1990; Kram, 1983; Payne \& Huffman, 2005). Cooper and Scartwright (1997) argue that the purpose of providing opportunities for personal interaction is not only for emotional support but also for the actual help that is needed to complete assigned tasks. In smaller enterprises, work relationships are much more personal and informal than in larger enterprises. This includes personal contacts on a daily basis between managers and employees (Hasle, Limborg, Kallehave, Klitgaard, \& Andersen, 2012; Matlay, 1999; Tsai, Sengupta, \& Edwards, 2007) requiring managers to maintain a good, close and friendly relationship with their workers (Down, 2006). Arguably, the smaller the enterprise, the more likely managers will have a better understanding of employees' needs and capabilities at work and responsibilities outside work, providing more appropriate and instant advice and support. Hence, we hypothesize that

Hypothesis 3: Good work relationship reduces employees' experience of work stress, and the association is likely to be stronger in SMEs than in large enterprises.

Organizational structure and climate can also make the working life either pleasant or stressful (Cooper \& Marshall, 1976). The level of the hierarchy, its flexibility and flatness determines the degree of which an employee can exert personal control and discretion over how to perform and complete the task, the scope of employee engagement in organizational issues and the efficiency of communication regarding organizational changes. Michie (2002) suggests that a culture of involving employees in decision-making, keeping them informed about what is happening in the organization and adequate consultation with employees can reduce job stress. This is particularly so in small enterprises, which are typified as being flatly and flexibly structured and operate in an informal and ad hoc 
manner in order to be competitive (Forth, Bewley, \& Bryson, 2006; Heneman \& Berkley, 1999). However, such enterprises lack financial resources, knowledge and time to offer employees extrinsic benefits and rewards (e.g. wages and financial benefits) (Kelloway \& Cooper, 2011). Rather, they emphasize intrinsic job qualities in terms of providing faster and more direct communication channels, offering varied working rules to suit the individual, giving more freedom to perform tasks and encouraging employees' participation in decision-making (Bolton Committee, 1971; Ingham, 1970). In contrast, large enterprises are organized in a more hierarchical, formal and inflexible way. Here, power and responsibilities are delegated to layers of middle managers so as to tackle the enhanced span of control (Kotey \& Slade, 2005), accompanied with highly formalized, standardized and routinized operational systems (Blau \& Schoenherr, 1971; Shikieri \& Musa, 2012). This results in bureaucracy, which can impede effective communication within and between different hierarchical levels. In addition, large enterprises are featured by higher capital intensity that requires employees to achieve a continuous utilization rate of the capital and therefore can hinder employee originated initiatives to control and influence their own job (e.g. work pace) (García-Serrano, 2008). Therefore, our fourth hypothesis suggests that

Hypothesis 4: Inflexible organizational structure and poor work environment increase employees' stress, but the effect is likely to be stronger in large enterprises than in SMEs.

Finally, small enterprises are generally absent of financial resources and knowledge (or extrinsic benefits) to have developed internal professional human resource functions and interventions to enhance employees' occupational health (Kelloway \& Cooper, 2011). Hence, their employees may be more exposed to certain occupational hazards (e.g. work overload and job insecurity) and thus increase work stress, particularly because of regulatory and compliance problems such as a reduced trade union presence and informal bargaining and dispute resolution mechanisms (Burgess, 1992). Small enterprises may still, however, outperform their large counterparts, and their employees report lower levels of work stress, because they are more likely to offer more satisfactory work relationships and working environments (Clark, 1996; Tansel \& Gazioglu, 2012), in terms of recognizing employees' needs, treating each worker differently, encouraging good social relations and satisfying intrinsic aspects of quality working life (Ingham, 1970). Indeed, data from the national Labour Force Survey show that smaller enterprises have lower prevalence rates of stress than larger enterprises (Health \& Safety Executive, 2012). Thus, our final hypothesis is as follows:

Hypothesis 5: Employees' experience of job stress is lower in SMEs than in large enterprises.

\section{Data}

The WERS2011 is the sixth in a government funded series of a nationally representative cross-section surveys, based on a stratified random sample of British establishments and a sample of employees at those establishments (for more detailed discussion, see Deepchand et al., 2013). WERS2011 includes an employment questionnaire consisting of a self-completion questionnaire distributed to a random sample to a maximum of 25 employees in the British workplaces with more than four employees $(n=21,981$; response rate $=54 \%)$. Also, it includes a management questionnaire ${ }^{2}$ consisting of face-to-face interviews with the most senior managers with the responsibility for employment relations in the establishment $(n=2680$; response rate $=46 \%)$. The sampled workers and establishments represent almost 23.3 million employees at 750,000 workplaces in the British economy excluding agriculture, forestry, fishing and mining and quarrying industry. In this paper, we matched the employer-employee data giving us the sample of 7182 employees from 1210 private organizations in the United Kingdom. ${ }^{3}$

\section{Job stress and job stressors}

Stress has been used to denote demands, which require the workers to readjust his/her usual behavioural patterns (Holmes \& Rache, 1967), or the state of physiological or emotional arousal that is caused by the perception of the demands (Lazarus \& Folkman, 1984; Selye, 1974; Thoits, 1995). In this paper, demands are terms as 'stressful aspects of job and work environment' or 'job stressors' (cf. explanatory variables) and the responses to these demands as 'employees' experience of overall job stress' (cf. dependent variables). During the development of the survey instruments, WERS questions were cognitively tested to examine clarity, recall and response processes.

Our dependent variable, employees' experience of overall job stress, was a factor analysed (Table I), and based on this, an index was constructed through the six questions in WERS2011 ${ }^{4}$ :

Q1: How much of the time has your job made you feel tense?

Q2: How much of the time has your job made you feel worried?

\footnotetext{
${ }^{2}$ The other two sections in the WERS 2011 are the Worker Representative Questionnaire and the Financial Performance Questionnaire. They are not used in the present study.

${ }^{3}$ Following previous work (e.g. Saridakis et al., 2013), our analysis is concern with private owned British workplaces only. WERS2011 originally comprises of 14,222 employees work in the private sector, so more than $50 \%$ of observations are remaining after missing data are dropped.

${ }^{4}$ The last three questions were newly added in WERS2011, and they were not available in WERS2004 (the fifth wave).
} 
Table I. Job stressor measurement

\begin{tabular}{|c|c|c|}
\hline Variable & \multicolumn{2}{|c|}{ Coding } \\
\hline \multicolumn{3}{|l|}{ Work overload } \\
\hline $\begin{array}{l}\text { Qualitative dimension: my job requires that I work very hard. } \\
\text { Quantitative dimension: I never seem to have } \\
\text { enough time to get my work done. }\end{array}$ & \multicolumn{2}{|c|}{$\begin{array}{l}\text { Strongly agree/agree }=1 \text { or neither agree nor } \\
\text { disagree/disagree/strongly disagree }=0\end{array}$} \\
\hline \multicolumn{3}{|l|}{ Job insecurity and poor promotion } \\
\hline I feel my job is secure in this workplace. & \multirow{2}{*}{\multicolumn{2}{|c|}{$\begin{array}{l}\text { Strongly agree/agree/neither agree or } \\
\text { disagree }=0 \text { or disagree/strongly disagree }=1 \\
\text { Strongly agree/agree }=1 \text { or neither agree } \\
\text { or disagree/disagree/strongly disagree }=0\end{array}$}} \\
\hline $\begin{array}{l}\text { People in this workplace who want to progress usually } \\
\text { have to put in long hours. }\end{array}$ & & \\
\hline & Factor loading & Cronbach's $\alpha$ \\
\hline Good work relationship* & & 0.93 \\
\hline Managers here can be relied upon to keep their promises. & 0.87 & \\
\hline Managers here are sincere in attempting to understand employees' views. & 0.91 & \\
\hline Managers here deal with employees honestly. & 0.90 & \\
\hline Managers here understand about employees' responsibilities outside workplace. & 0.79 & \\
\hline Managers here encourage people to develop their skills. & 0.79 & \\
\hline Managers here treat employees fairly. & 0.88 & \\
\hline \multicolumn{3}{|l|}{ Organizational structure and climate } \\
\hline Poor job autonomy ${ }^{\dagger}$ & & 0.86 \\
\hline In general, how much influence do you have over the tasks you do? & 0.83 & \\
\hline In general, how much influence do you have over the pact at which you work? & 0.82 & \\
\hline In general, how much influence do you have in how you do your work? & 0.88 & \\
\hline In general, how much influence do you have in order to carry out tasks? & 0.84 & \\
\hline Poor communication ${ }^{\ddagger}$ & & 0.91 \\
\hline How good are managers at telling about changes in how organization is run? & 0.92 & \\
\hline How good are managers at informing employees about changes in staffing? & 0.91 & \\
\hline $\begin{array}{l}\text { How good are managers at informing staff about changes in the } \\
\text { way you do your job? }\end{array}$ & 0.89 & \\
\hline How good are managers at informing staff about financial matters? & 0.84 & \\
\hline Poor employee engagement ${ }^{\ddagger}$ & & 0.93 \\
\hline $\begin{array}{l}\text { Overall, how good are managers at seeking views of employees } \\
\text { or employee reps? }\end{array}$ & 0.93 & \\
\hline $\begin{array}{l}\text { How good are managers responding to suggestions from employees } \\
\text { or employee reps? }\end{array}$ & 0.95 & \\
\hline $\begin{array}{l}\text { How good are managers at allowing employees or worker reps } \\
\text { influence final decision? }\end{array}$ & 0.93 & \\
\hline Employees' experience of overall job stress ${ }^{\S}$ & & 0.91 \\
\hline How much of the time has your job made you feel tense? & 0.75 & \\
\hline How much of the time has your job made you feel worried? & 0.87 & \\
\hline How much of the time has your job made you feel uneasy? & 0.80 & \\
\hline How much of the time has your job made you feel depressed? & 0.87 & \\
\hline How much of the time has your job made you feel gloomy? & 0.84 & \\
\hline How much of the time has your job made you feel miserable? & 0.84 & \\
\hline
\end{tabular}

$n=7182$ employees; 1120 organizations.

${ }^{*}$ Responses are coded on five-point Likert scale: strongly agree $=5$, agree $=4$, neither agree nor disagree $=3$, disagree $=2$ or strongly disagree $=1$.

${ }^{\dagger}$ Responses are coded on four-point Liker scale: a lot $=1$, some $=2$, a little $=3$ or none $=4$.

${ }^{*}$ Responses are coded on five-point Likert scale: very $\operatorname{good}=1$, $\operatorname{good}=2$, neither good nor poor $=3$, poor $=4$ or very poor $=5$.

${ }^{S}$ Responses are coded on five-point Likert scale: never $=1$, occasionally $=2$, some of the time $=3$, most of the time $=4$ or all the time $=5$.

Q3: How much of the time has your job made you feel uneasy?

Q4: How much of the time has your job made you feel depressed?
Q5: How much of the time has your job made you feel gloomy?

Q6: How much of the time has your job made you feel miserable? 
The responses were indicated on a five-point Likert scale, where 'all of the time' $=5$, 'most of the time' $=4$, 'some of the time' $=3$, 'occasionally' $=2$ or 'never' $=1$ (Cronbach's $\alpha=0.91$ ).

Job stressors are operationalized as the degree of stress perceived in work-related events and situations (Chan et al., 2000). The An Organizational Stress Screening Tool (ASSET) Questionnaire developed by Cartwright and Cooper (2002) serves as a short instrument suitable for identifying potential stress problems (Appendix, Table A1). The ASSET Scale has a small number of reliable factors for ease of interpretation and excellent convergent validity (Faragher, Cooper, \& Cartwright, 2004; Johnson \& Cooper, 2003). In WERS2011, a list of 21 work-related events and situations (Table I) were presented to employee respondents to indicate whether or not they have experienced the situation, which is similar to those in the ASSET Questionnaire. Table I shows that eight specific job stressors were identified and constructed. Four binary job stressors, including qualitative and quantitative work overload and job insecurity and promotion opportunities, were measured based on single statements. The remaining four potential sources of stress (e.g. negative work relationship, poor job autonomy, communication and employees' engagement) were measured with different items and an index was constructed for each one.

\section{Enterprise size and other explanatory variables}

Enterprise size is determined by the total number of employees in the organization. The WERS data mainly include information on workplace size, but it also identifies workplaces within multisite enterprises and asks the number of employees in the organization of which the workplace is part. Following Storey et al. (2010) and Saridakis, Torres, and Johnstone (2013), we construct an enterprise size, which lies with the standard European definition: Firms having less than 250 employees are SMEs, and those with 250 or more are large enterprises.

We also control for a wide range of individual and organizational characteristics in the estimations. ${ }^{5}$ For example, we include information on job tenure, contractual status, gender, age, marital status, number of children, caring responsibility, long-term illness, academic qualification and weekly pay. Also, work condition changes experienced by employees as a result of recession (e.g. workload increased, access to paid overtime restricted, access to training restricted, etc.) are also considered in the specification. Dekker and Barling (1995) suggest that employees are less likely to experience certain job stressors (e.g. work overload and job insecurity) when they are offered comprehensive benefits

\footnotetext{
${ }^{5}$ The statistics summary is presented in Appendix Table A2.
}

by the employers (so called organizational supports) through the adoption of certain formal human resource (HR) policies and practices. Hence, a variable that captures the objective organizational supports proxied by 11 formal HR policies (Cronbach's $\alpha=0.72$ ) similar to those adopted by Dekker and Barling (1995) is constructed and controlled in the estimation.

\section{Results and analysis}

We start the analysis by showing weighted averages (to minimize potential biases introduced by the sample selection and response process) of the measures capturing employees' experience of job stress and sources of stress for SMEs and large enterprises. Table II shows that the averages of qualitative work overload are symmetrical between SMEs and large enterprises. However, quantitative work overload, job insecurity and poor promotion opportunities increase as enterprise size increases. This is probably because most SMEs included in our sample are solely or family-owned (Wanrooy et al., 2013) and are more likely to be run by owner managers who use informal methods in relation to recruitment (e.g. hired people that are acquainted with owners rather than outsiders) and promotion opportunities. We also find that enterprise size is positively and significantly related with poor work relationships and organizational environment (manifested in job autonomy, communication and employee engagement). In addition, the results suggest that job stress is lower in SMEs than in large enterprises. This may be linked to small firms offering 'packages' that emphasize nonmonetary benefits such as autonomy, involvement and intrinsic job qualities (Ingham, 1970; Storey, 1992), and workers involved in this open and flexible working environment are more likely to be satisfied with their jobs ( Idson, 1990; Storey et al., 2010).

We continue our analysis by modelling job stress, considering a wide range of covariates discussed previously and estimating our model and using ordinary least squares (OLS) and ordered probit model (Wooldridge, 2002). ${ }^{6}$ For the latter approach, the overall job stress was ordered on a five-point Likert scale, in terms of grouping the observation in the near discrete value of 1, 2, 3, 4 and 5. We also split the overall sample between SMEs and large enterprises to capture potential enterprise size differences. Table III presents the OLS and ordered probit results for the overall sample and different sized enterprises. The results are found to be similar across the two specifications. They suggest that both qualitative and quantitative work overloads are significantly and positively associated with

\footnotetext{
${ }^{6}$ We also adopt a random effects estimator to allow for the fact that the employee level data are drawn from a number of workplaces and thus, to control for potential unobservable intrafirm correlation. The results are found to be similar to those reported from the OLS model and ordered probit model.
} 
Table II. Averages for employees' experience of job stress and job stressors (weighted estimation)

\begin{tabular}{|c|c|c|c|}
\hline Sample size & SMEs & Large enterprises & Adjusted Wald test \\
\hline & & Mean & Difference $(\%)$ \\
\hline \multicolumn{4}{|l|}{ Job stressors } \\
\hline \multicolumn{4}{|l|}{ Work overload } \\
\hline Qualitative dimension & 0.83 & 0.83 & - \\
\hline Quantitative dimension & 0.35 & 0.40 & $\underline{14}$ \\
\hline \multicolumn{4}{|l|}{ Poor career prospects } \\
\hline Job insecurity & 0.13 & 0.16 & 23 \\
\hline Poor promotion opportunity & 0.36 & 0.47 & 31 \\
\hline \multicolumn{4}{|l|}{ Good work relationship } \\
\hline Managers here can be relied upon to keep their promises. & 3.54 & 3.28 & -7 \\
\hline Managers here are sincere in attempting to understand employees' views. & 3.67 & 3.37 & -8 \\
\hline Managers here deal with employees honestly. & 3.71 & 3.43 & -8 \\
\hline Managers here understand about employees' responsibilities outside workplace. & 3.76 & 3.47 & -8 \\
\hline Managers here encourage people to develop their skills. & 3.63 & 3.47 & -4 \\
\hline Managers here treat employees fairly. & 3.69 & 3.43 & -7 \\
\hline Average scores across six items & 3.68 & 3.41 & -7 \\
\hline \multicolumn{4}{|l|}{ Poor job autonomy } \\
\hline In general, how much influence do you have over the tasks you do? & 1.70 & 1.89 & 11 \\
\hline In general, how much influence do you have over the pact at which you work? & 1.76 & 1.96 & 11 \\
\hline In general, how much influence do you have in how you do your work? & 1.52 & 1.68 & 11 \\
\hline In general, how much influence do you have in order to carry out tasks? & 1.56 & 1.72 & 10 \\
\hline Average scores across four items & 1.63 & 1.81 & 11 \\
\hline \multicolumn{4}{|l|}{ Poor communication } \\
\hline How good are managers at telling about changes in how organization is run? & 2.47 & 2.56 & 4 \\
\hline How good are managers at informing employees about changes in staffing? & 2.49 & 2.72 & 9 \\
\hline How good are managers at informing staff about changes in the way you do your job? & 2.43 & 2.58 & 6 \\
\hline How good are managers at informing staff about financial matters? & 2.73 & 2.72 & 0 \\
\hline Average scores across four items & 2.53 & 2.65 & $\underline{5}$ \\
\hline \multicolumn{4}{|l|}{ Poor employees' engagement } \\
\hline Overall, how good are managers at seeking views of employees or employee reps? & 2.55 & 2.74 & 7 \\
\hline How good are managers responding to suggestions from employees or employee reps? & 2.57 & 2.83 & 10 \\
\hline How good are managers at allowing employees or worker reps influence final decision? & 2.81 & 3.07 & 9 \\
\hline Average scores across three items & 2.64 & 2.88 & 9 \\
\hline \multicolumn{4}{|l|}{ Employees' experience of job stress } \\
\hline How much of the time has your job made you feel tense? & 2.50 & 2.63 & 5 \\
\hline How much of the time has your job made you feel worried? & 1.68 & 1.81 & 8 \\
\hline How much of the time has your job made you feel uneasy? & 2.01 & 2.09 & $\underline{4}$ \\
\hline How much of the time has your job made you feel depressed? & 1.77 & 1.91 & $\overline{8}$ \\
\hline How much of the time has your job made you feel gloomy? & 1.81 & 1.98 & 9 \\
\hline How much of the time has your job made you feel miserable? & 1.64 & 1.77 & 8 \\
\hline Average scores across six items & 1.90 & 2.03 & 7 \\
\hline
\end{tabular}

$N_{\text {SMEs }}=2250$ employees, 470 small and medium sized enterprises. $N_{\text {large enterprises }}=4977$ employees and 560 large organizations.

Bold, underlined and italic values indicate where differences was found to be statistically significant at $1 \%, 5 \%$ and $10 \%$ level, respectively. SMEs: small and medium-sized enterprises.

employees' experience of overall job stress in SMEs, thus providing support for Hypothesis 1. Our findings may be partly explained by the fact that smaller enterprises have a limited workforce in comparison with large enterprises. Hence, their employees are more likely to perform tasks without a specific job description, are expected to undertake incompatible tasks and are likely to complete excessive amount of workloads in a given time period (Chuang, 2006). The coefficient for qualitative work overload, however, appears to be smaller in SMEs than in large enterprises.

Job insecurity and poor career promotion opportunities, as important components of employees' 
Table III. Estimates of the employees' experience of overall job stress: overall sample

\begin{tabular}{|c|c|c|c|c|c|c|}
\hline \multirow{2}{*}{$\begin{array}{l}\text { Sample size } \\
\text { Regression specifications }\end{array}$} & \multicolumn{2}{|c|}{ Overall } & \multicolumn{2}{|c|}{ SMEs } & \multicolumn{2}{|c|}{ Large enterprises } \\
\hline & OLS & $\begin{array}{c}\text { Ordered probit } \\
\text { regression }\end{array}$ & OLS & $\begin{array}{l}\text { Ordered probit } \\
\text { regression }\end{array}$ & OLS & $\begin{array}{l}\text { Ordered probit } \\
\text { regression }\end{array}$ \\
\hline \multirow{3}{*}{ Large enterprises (base category: SMEs) } & Coefficients & Coefficients & Coefficients & Coefficients & Coefficients & Coefficients \\
\hline & -0.010 & -0.001 & - & - & - & - \\
\hline & 0.022 & 0.035 & & & & \\
\hline \multicolumn{7}{|l|}{ Job stressors } \\
\hline \multirow[t]{2}{*}{ Qualitative work overload } & $0.137^{\star * *}$ & $0.248^{\star * *}$ & $0.082^{\star *}$ & $0.197^{\star * *}$ & $0.164^{* * *}$ & $0.268^{\star * *}$ \\
\hline & 0.023 & 0.040 & 0.041 & 0.072 & 0.027 & 0.048 \\
\hline \multirow[t]{2}{*}{ Quantitative work overload } & $0.373^{\star * *}$ & $0.546^{\star * *}$ & $0.430^{\star * *}$ & $0.636^{\star \star *}$ & $0.345^{\star * *}$ & $0.505^{\star * *}$ \\
\hline & 0.020 & 0.030 & 0.033 & 0.050 & 0.024 & 0.038 \\
\hline \multirow[t]{2}{*}{ Job insecurity } & $0.285^{\star * *}$ & $0.356^{\star * *}$ & $0.330^{* * *}$ & $0.412^{\star * *}$ & $0.267^{\star * *}$ & $0.338^{\star * *}$ \\
\hline & 0.030 & 0.041 & 0.052 & 0.073 & 0.037 & 0.050 \\
\hline \multirow[t]{2}{*}{ Poor promotion } & $0.101^{\star * *}$ & $0.177^{\star \star *}$ & $0.103^{\star * *}$ & $0.145^{\star \star *}$ & $0.098^{\star * *}$ & $0.196^{\star * *}$ \\
\hline & 0.018 & 0.029 & 0.030 & 0.048 & 0.023 & 0.036 \\
\hline \multirow[t]{2}{*}{ Good work relationship } & $-0.294^{\star * *}$ & $-0.400^{\star * *}$ & $-0.304^{\star * *}$ & $-0.414^{\star * \star}$ & $-0.290^{\star * *}$ & $-0.393^{\star * *}$ \\
\hline & 0.019 & 0.028 & 0.031 & 0.045 & 0.023 & 0.036 \\
\hline \multirow[t]{2}{*}{ Poor job autonomy } & $0.080^{\star * *}$ & $0.134^{\star * *}$ & $0.055^{\star *}$ & $0.094^{\star *}$ & $0.091^{\star * *}$ & $0.153^{* * *}$ \\
\hline & 0.016 & 0.023 & 0.027 & 0.041 & 0.018 & 0.027 \\
\hline \multirow[t]{2}{*}{ Poor communication } & $0.030^{\star}$ & $0.047^{\star *}$ & $0.041^{\star}$ & $0.073^{\star \star}$ & 0.025 & 0.036 \\
\hline & 0.015 & 0.022 & 0.025 & 0.036 & 0.020 & 0.029 \\
\hline \multirow[t]{2}{*}{ Poor employee engagement } & $0.035^{\star *}$ & $0.072^{\star * *}$ & 0.017 & 0.047 & $0.043^{* *}$ & $0.084^{* * *}$ \\
\hline & 0.016 & 0.025 & 0.027 & 0.040 & 0.020 & 0.031 \\
\hline Controls & Yes & Yes & Yes & Yes & Yes & Yes \\
\hline Log likelihood & - & -7699.12 & - & -2790.95 & - & -4884.81 \\
\hline$\chi^{2}$ (Degrees of freedom) & - & 2434.24(37) & - & $1231.71(36)$ & - & 1446.91(36) \\
\hline Adjusted $R^{2}$ & 0.34 & - & 0.36 & - & 0.34 & - \\
\hline Observations & 7182 & 7182 & 2658 & 2658 & 4524 & 4524 \\
\hline
\end{tabular}

In total, there are 1120 organizations consisting of 470 SMEs and 650 large enterprises.

All models control a wide range of individual and organizational characteristics. Results for SMEs and large enterprises are available upon request. Results for overall sample are presented in the Appendix, Table A3.

All models have been adjusted for clustering.

Standard errors are reported beneath parameter estimates (in italic).

We have also experimented with more details models including, e.g. industry and ethnicity variables. Including the industry variables (e.g. manufacturing, wholesale and retail, financial and real estate activities, entertainment and recreation) the results remained largely unenhanced, but most of the industry variables are found to have weak association with employees' experience of job stress. In contrast, ethnic background seems to have a significant effect on experience of job stress with British workers to feel lower levels of stress than non-British workers (results are available upon request).

OLS: ordinary least squares; SMEs: small and medium-sized enterprises.

${ }^{\star} p<0.10$.

${ }^{* *} p<0.05$.

${ }^{* * *} p<0.01$.

career prospects, are found to be positively related to stressful experience of work in SMEs, suggesting that employment security and a promising career path are important to employees' quality of work life. Although employees in smaller enterprises found to have lower averages in job insecurity and poor progression than employees working in large enterprises (Table II), changes in these job circumstances are found to have greater impact on SMEs than on large enterprises. Overall, the results provide strong support of Hypothesis 2 and are in line with the mainstream view that employment security and career development improve with enterprise size (Anderson \& Pontusson, 2007).
In contrast, a good work relationship reflected in employee's perception of managerial supports and trust in management is found to have negative and significant associations with employees' experience of work stress in both SMEs and larger enterprises with the effects being slightly higher for the former enterprises. Therefore, we find support of Hypothesis 3. One possible explanation of this result is that small business enterprises lack the number of employees to make extrinsic benefits feasible, the resources to provide them and the personnel to administer them (Dekker \& Barling, 1995). Rather, their employees may balance intrinsic job qualities including close working relationship against relatively poor financial benefits and objective 
organizational supports (Ingham, 1970). Therefore, a close and supportive relationship between employees and their managers are probably more critical to alleviate employees' experience of work stress in small enterprises than in large ones.

Regarding what has been manifested in employees' discretion over the work-specifically autonomy, communication and employees' engagement-we find that inflexible working rules and poor organizational structure/environment increase stressful working experience in SMEs, but some of the effects are more apparent for large enterprises. In general, our results provide support of Hypothesis 4 and also are closely aligned with the perspective that 'small is beautiful'. It is commonly perceived, for example, that small firms offer better employment conditions, intrinsic job satisfaction, varied work and opportunities for employees to feel closer to objectives and direction of the firm (Bolton Committee, 1971; Storey, 1992) than large enterprises. Also, employees in small enterprises enjoy a more open and flexible work environment involving self-responsible teams, more low-level employee involvement in decision-making and an overall more horizontal communication and management style (Artz, 2008).

Finally, unlike the results presented in Table II, enterprise size is not found to be associated with employees' experience of overall job stress after controlling for a number of covariates. Thus, a pure size effect as discussed by Tsai et al. (2007) and other commentators (Kalleberg \& Van Buren, 1996; Storey et al., 2010 ) is found to be insignificantly related to job stress. Thus, Hypothesis 5 is rejected. The enterprise size effect is potentially covered by a wide range of stressful aspects of the job and work environment (or job stressors) reflecting the structural and contextual characteristics of the enterprises.

We also find some statistically significant relationships between employees' experience of overall job stress and individual and organizational characteristics. These findings are reported in the Appendix, Table A3. For example, the longer the employees have been working for the current employer, the higher the job stress they experience, which is probably caused by increased employee commitment to the organization. Older employees, in particular those older than 60 years, are found to have lower level of job stress, especially as they approach retirement age. We also find that long-term illness is positively related to job stress since health problems may lead to physical strains. Moreover, we find that individuals with supervision responsibilities are disposed more to work stress than those who have no such responsibility. Also, employees who are paid in the higher category of weekly wage face a larger amount of work stress than those who received the lowest level of pay. Lastly, formalization of HR policies is found to be associated with lower levels of job stress, whereas employees' experiences of job stress is greater in the organizations where some measures (e.g. pay freeze) has been taken into action due to the recent recession.

\section{Conclusion and implications}

This paper has sought to examine the relationship between firm size and employees' experience of work and focuses specifically on job stress, following Cooper and Marshall's model (1976). We examine how employees' experience of job stress varies between SMEs and large enterprises, in terms of studying the effect of stressful aspects of work on employees' experience of job stresses in SMEs and large enterprises. In line with previous studies (e.g. Cartwright \& Cooper, 2002; Coetzee \& De Villiers, 2010; Coetzer \& Rothmann, 2007; Rollinson, 2005), we find that work overload, poor career prospects, negative work relationships and inflexible work environment all increase job stress. However, our analysis examines the effects of these factors separately for SMEs and large enterprises and finds that the magnitude of the impact of each job stressor differs significantly by enterprise size. In particular, quantitative work overload, job insecurity and poor career progression, good work relationships and poor communication appear to have stronger impact on employees' experience of job stress in SMEs. On the other hand, qualitative work overload, poor job autonomy and employee engagement are more important stressors in larger enterprises. We also examine the direct association between firm size and employees' experience of job stress. However, our finding does not support the presence of a pure size effect as identified by Tsai et al. (2007).

The paper has some clear implications for practitioners. It provides a good understanding of the importance of various antecedents of job stress in different size of organizations. This may be used to design more efficient and appropriate work environment interventions and management practices to alleviate employees' experience of work stress in different organizational settings. For managers and policy makers, it is important to make sure that job demands match the knowledge, capabilities and resource of workers to prevent overload. Cooper and Scartwright (1997) suggest that employees should be given increased control and discretions over challenging tasks and necessary provisions to recover from demanding tasks. Also, employers should constantly inform and update the organizational development that may influence workers' employment and avoid any ambiguity when offering employees opportunities for career development (Michie, 2002). Jobs should be designed to encourage personal interaction within a work group as well as between superiors and workers, which can enhance mutual trust and offer individuals actual help that they need to complete the tasks.

For smaller organizations, resources may be allocated to develop formal management practices and supportive organizational schemes, in particular, 
occupational and skill development programs for further career progression. However, some authors argue that increasing formalization in management practices may not be appreciated by employees in small enterprises, where the workplace is already flexible and intrinsically rewarding within in the context of informality (e.g. Saridakis et al., 2013; Verreynne, Parker, \& Wilson, 2013). Management in smaller enterprises should be aware that identifying and employing an optimum level of HR structure and processes that balances the tension between formality and informality of management practices is challenging but also beneficial (Marlow \& Patton, 2002). For policy makers, government intervention should be targeted on smaller enterprises to help them to comply with the government's rules and regulations where they affect this optimum HR structure. More important, policy interventions should be conscious of a compulsive shift towards greater formality. The unique nature of small enterprises requires a certain level of informality and flexibility in the employment relations for their survival and competitive success (Sheehan, 2013).

Our analysis also has implications for research. We have used a number of employees in the enterprise to proxy organization size. However, further research may benefit from a multidimensional approach to the concept of size. Besides employment size, other variables that measure the scale of business operation (e.g. total assets or sales/revenue) should be considered and incorporated in the future analysis. The present study also examines the direct relationship between firm size and each job stressor. Future research may look into the possible organizational process that may mediate these relationships. For instance, Dekker and Barling (1995) identified the mediating role of perceived organizational support in the relationship between firm size and role stressors. Hence, it is possible that size may exert an indirect impact on certain job stressors (e.g. job insecurity and career development and work overload) through positive extrinsic benefits (e.g. infringe benefits and health and safety committee), which are expected to be negatively related to those stressful aspects of the job. Last but not the least, the unexpected negative relationship of firm size to career prospects and quantitative work overload suggests that the association between size and job security/promotion opportunities may be mediated by other factors, such as better terms and conditions and protection against unfair dismissals, rather than solely determined by tangible rewards. This also merits further investigation.

\section{Conflict of interest}

The authors have declared that they have no conflict of interest.

\section{REFERENCES}

Ahsan, N., Abdullah, Z., Fie, D.Y.G., \& Alam, S.S. (2009). A study of job stress on job satisfaction among university staff in Malaysia: Empirical study. European Journal of Social Sciences, 8, 121-131.

Anderson, C.J., \& Pontusson, J. (2007). Workers, worries and welfare states: Social protection and job insecurity in 15 OECD countries. European Journal of Political Research, 46, 211-235.

Argyris, C. (1964). Integrating the individual and the organisation. New York: Wiley.

Artz, B. (2008). The role of firm size and performance pay in determining employee job satisfaction. Labour, 22(2), 315-343.

Bacon, N., Ackers, P., Storey, J., \& Coates, D. (1996). It is a small world: Managing human resource in small business. The International Journal of Human Resource Management, 7, 82-100.

Beehr, A.T., Jex, M.S., Stacy, A.B., \& Murray, A.M. (2000). Work stressors and co-worker support as predictors of individual strain and job performance. Journal of Organisational Behaviour, 21, 391-405.

Blau, P., \& Schoenherr, R. (1971). The structure of organisation. New York: Basic Books.

Bolton Committee. (1971). Report of the committee of inquiry on small firms. Cmnd 4811. London: Her Majesty's Stationery Office.

Burgess, J. (1992). Further evidence on small business employment and industrial relations. Labour Economics and Productivity, 4, 130-149.
Buultjens, J., \& Orme, F. (2002). Industrial relations reform and the small business sector. The Drawing Board: An Australian Review of Public Affairs, 3, 105-120.

Carroll, M., Marchington, M., Earnshaw, J., \& Taylor, S. (1999). Recruitment in small firms: Processes, methods and problems. Employee Relations, 21, 236-250.

Cartwright, S., \& Cooper, C.L. (2002). ASSET: An organisational stress screening tool - the management guide. Manchester: RCL Ltd.

Chan, K.B., Lai, G., Ko, Y.C., \& Boey, K.W. (2000). Work stress among six professional groups: The Singapore experience. Social Science and Medicine, 50, 1415-1432.

Chandola, T. (2010) Stress at work. A report prepared for the British Academy. The British Academy. ISBN 978-0-85672-589-0. London.

Chuang, Y. (2006). Occupational and employee stress in small business. Journal of International Management Studies, 1, 1-13.

Clark, A.E. (1996). Job satisfaction in Britain. British Journal of Industrial Relations, 34, 189-217.

Clarke, S.(2011). Obstacles, challenges and potential solutions. In E.K. Kelloway, \& C.L. Cooper (Eds.), Occupational health and safety for small and medium sized enterprises (pp. 7-25). Cheltenham: Edward Elgar Publishing Limited.

Coetzee, M., \& De Villiers, M.A. (2010). Source of job stress, work engagement and career orientations of employees in a South African financial institution. South African Business Review, 14, 27-57.
Coetzer, C.F., \& Rothmann, S. (2007). Job demands, job resources and work engagement of employees in a manufacturing organisation. South African Business Review, 11(1), 17-32.

Cooper, C.L. (1973). Group training for individual and organisational development. Basel, Switzerland: S. Karger. Cooper, C.L., \& Marshall, J. (1976). Occupational source of stress: A review of the literature relating to coronary heart disease and mental ill health. Journal of Occupational Psychology, 40, 11-28.

Cooper, C.L., \& Scartwright, S.(1997). An intervention strategy for workplace stress. Journal of Psychosomatic Research, 43, 7-16.

Cooper, C.L., Kirkcaldy, B.K., \& Brown, J. (1994). A model of job stress and physical health: The role of individual differences. Personality and Individual Differences, 16, 653-655.

Dekker, I., \& Barling, J. (1995). Workforce size and work-related role stress. Work and Stress, 9(1), 45-54.

Deepchand, K., Drever, E., Gilby, N., Prestage, Y., Purdon, S., Tipping, S., \& Wood, M. (2013). Workplace Employment Relations Survey (WERS) 2011/12: Technical Report. London: NatCen Social Research.

Down, S. (2006). Narratives of enterprise: Crafting entrepreneurial self-identify in a small firm. Cheltenham: Edward Elgar.

Dreher, G.F., \& Ash, R.A. (1990). A comparative study of mentoring among men and women in managerial, professional, and technical positions. Journal of Applied Psychology, 75, 539-546. 
Dyer, S., \& Quine, L. (1998). Predictors of job satisfaction and burnout among the direct care staff of a community learning disability service. Journal of Applied Research in Intellectual Disabilities, 11, 320-332.

Faragher, E.B., Cooper, C.L., \& Cartwright, S. (2004). A shortened stress evaluation tool (ASSET). Stress and Health, 20, 189-201.

Forth, J., Bewley, H., \& Bryson, A. (2006). Small and medium-sized enterprises: Findings from the 2004 workplace employment relations survey. Retrieved from Jan 5, 2013, from: http://www.bis.gov.uk/files/ file31580.pdf

French, J.R.P., \& Caplan, R.D. (1973). Organisational stress and individual strain. In Marrow A.J. (Ed.), The failure of success. New York: AMACOM.

García-Serrano, C. (2008). Does size matter? The influence of firm size on working conditions and job satisfaction. ESRC. Institute for Social and Economic Research, University of Essex.

Glisson, C., Dukes, D., \& Green, P. (2006). The effects of the ARC organisational intervention on caseworker turnover, climate and culture in childern's service systems. Child Abuse and Neglect: The International Journal, 30, 855-880.

Hasle, P., Limborg, H.J., Kallehave, T., Klitgaard, C., \& Andersen, T.R. (2012). The working environment in small firms: Responses from owner-managers. International Small Business Journal, 30(6) 622-639.

Health and Safety Executive. (2007). Workplace stress costs Great Britain in excess of $£ 530$ million. Available on: http://www.hse.gov.uk/press/2007/ c07021.htm.

Health and Safety Executive. (2012). Stress and psychological disorder. Available on: http://www.hse.gov.uk/ statistics/causdis/stress/stress.pdf.

Heneman, III. H.G., \& Berkley, R.A. (1999). Applicant attraction practices and outcomes among small businesses. Journal of Small Business Management, 37, 53-74.

Holmes, T.H., \& Rache, R.H. (1967). The social readjustment rating scale. Journal of Psychosomatic Research, 11, 213-218.

Idson, T.L. (1990). Firm size, job satisfaction and the structure of work. Applied Economics, 22, 1007-1018.

Idson, T.L. (1996). Employee size and labour turnover. In S.W. Polatchek (Ed.), Research in labour economics. Greenwich, CT: JAI Press.

Idson, T.L., \& Oi, W. (1999). Workers are more productive in large firms. American Economic Review: Papers and Proceedings, 89, 104-108.

Ingham, G.K. (1970). Size of industrial organisation and worker behaviour. Cambridge: Cambridge University Press.

Jackson, S.E., Schuler, R.S., \& Rivero, J.C. (1989). Organisational characteristics as predictors of personnel practices. Personnel Psychology, 42, 727-786.

Jamal, M. (1990). Relationship of job stress and type-A behaviour to employee job satisfaction, organisational commitment, psychosomatic health problems and turnover motivation. Human Relations, 43, 727-738.

Johnson, S., \& Cooper, C. (2003). The construct validity of the ASSET stress measure. Stress and Health, 19, 181-185. Johnson, S., Cooper, C., Cartwright, S., Danald, I., Taylor, P., \& Millet, C. (2005). The experience of work-related stress across occupations. Journal of Managerial Psychology 20, 178-187.

Kahn, R.L., \& Byosiere, P. (1992). Stress in organisations. In M.D. Dunnett (Ed.), Handbook of industrial and organisational psychology. Palo Alto, CA: Consulting Psychologists Press.

Kalleberg, A.L., \& Van Buren, M.E. (1996). Is bigger better? Explaining the relationship between organization size and job rewards. American Sociological Review, 61(1), 47-66.

Kelloway, E.K., \& Cooper, C.L. (2011). Introduction: Occupational health and safety in small and medium sized enterprises. In E.K. Kelloway, \& C.L. Cooper (Eds.), Occupational health and safety for small and medium sized enterprises (pp. 1-6). Cheltenham: Edward Elgar Publishing Ltd.

Kok, J., Vroonhof, P., Werhoeven, W., Timmermans, N., Kwaak, T., Snijders, J., \& Westhof, F. (2011). Do SMEs create more and better jobs? EIM Business and Policy Research.

Kotey, B. (1999). Human resource management practices of gold coast small firms. International Journal of Employment Studies, 7, 79-104.

Kotey, B., \& Slade, P. (2005). Formal human resource management practices in small growing firms. Journal of Small Business Management, 43, 16-40.

Kram, K.E. (1983). Phases of the mentor relationship. Academy of Management Journal, 26, 608-625.

Lazarus, R.S., \& Folkman, S. (1984). Stress, appraisal and coping. New York: Springer.

Leka, S., Griffiths, A., \& Cox, T. (2004). Work organisation and stress: Systematic problem approaches for employees, managers and trade union representatives. World Health Organisation Protecting Workers' Health Series No.3.

Logan, M.S., \& Ganster, D.C. (2005). An experimental evaluation of a control intervention to alleviate job-related stress. Journal of Management, 31, 90-170.

Man, T.W., Lau, T., \& Chan, K.F. (2001). The competitiveness of small and medium enterprises: A conceptualisation with focus on entrepreneurial competencies. Journal of Business Venturing, 17, 123-142. Marlow, S., \& Patton, D. (2002). Minding the gap between employers and employees: The challenge for owner-managers of smaller manufacturing firms. Employee Relations, 24, 523-539.

Matlay, H. (1999). Employee relations in small firms: A micro-business perspective. Employee Relations, 21, 285-295.

Michael, O., Court, D., \& Petal, P. (2009). Job stress and organisational commitment among mentoring coordinators. International Journal of Educational Management, 23, 266-288.

Michie, S. (2002). Causes and management of stress at work. Occupational and Environmental Medicine, 59, 67-72.

Nakao, M. (2010). Work-related stress and psychosomatic medicine. BioPsychosocial Medicine, 4, 4-11.

Nelson, D.L., \& Burke, R.J. (2000). Women executives: Health, stress, and success. Academy of Management Executive, 14, 107-121.

Noblet, A., \& Lamontagne, A.D. (2006). The role of workplace health promotion in addressing job stress. Health Promotion International, 21, 346-353.
Payne, S.C., \& Huffman, A.H. (2005). A longitudinal examination of the influence of mentoring on organisational commitment and turnover. The Academy of Management Journal, 48, 158-168.

Rahim, M.A. (1992). A model of stress, strain, locus of control, social support and propensity to leave a job: A field study with entrepreneurs and managers. Paper presented at the Annual Meeting of the National Academy of Management, Las Vegas, NV.

Rainnie, A. (1989). Industrial relations in small firms: Small isn't beautiful. London and New York: Routledge.

Rizzo, J., House, R., \& Lirtzman, S. (1970). Role conflict and ambiguity in complex organisations. Administrative Science Quarterly, 15, 150-163.

Rollinson, D. (2005). Organisational behaviour and analysis: An integrated approach. London: Prentice-Hall.

Saridakis, G., Torres, R.B., \& Johnstone, S. (2013). Do human resource practices enhance organisational commitment in SMEs with low employee satisfaction? British Journal of Management, 24(3), 445-458.

Selye, H. (1974). Stress without distress. Philadelphia: J. B. Lippincott Company.

Sheehan, M. (2013). Human resource management and performance: Evidence from small and medium-sized firms. International Small Business Journal. DOI:10.1177/0266242612465454.

Shikieri, A.B.E., \& Musa, H.A. (2012). Factors associated with occupational stress and their effects on organisational performance in a Sudanese University. Creative Education, 3, 134-144.

Storey, D.J. (1992). Development in the management of human resource. Oxford: Blackwell.

Storey, D.J., Saridakis, G., Sen-Gupta, S., Edwards, P.K., \& Blackburn, R.A. (2010). Linking HR formality with employee job quality: The role of firm and workplace size. Human Resource Management, 49, 305-329.

Tansel, A., \& Gazioglu, S. (2012). Managementemployee relations, firm size and job satisfaction. Economic Research Centre Working Papers in Economics 12/11.

Thoits, P. (1995). Stress, coping and social support processes: Where are we? What next? Journal of Health and Social Behaviour, Extra Issue, 53-79.

Ton, Z., \& Huckman, R.S. (2008). Managing the impact of employee turnover on performance: The role of process conformance. Organisation Science, 19, $56-68$.

Tsai, C.J., Sengupta, S., \& Edwards, P. (2007). When and why is small beautiful? The experience of work in the small firm. Human Relations, 60, 1779-1807.

Urwin, P., Karuk, V., Buscha, F., \& Siara, B. (2008). Small business in the UK: New perspectives on evidence and policy. Commissioned by the Federation of Small Businesses. Retrieved 15 Feb, 2013, from: http://www.fsb.org.uk/policy/images/ fsbwestminster01\%2012\%20(3).pdf

Vakola, M., \& Nikolaou, I., (2005). Attitudes towards organisational change: What is the role of employees' stress and commitment? Employee Relations, 27, 160-174.

Verreynne, M.L., Parker, P., \& Wilson, M. (2013). Employment systems in small firms: A multilevel analysis. International Small Business Journal, 31(4), 405-431. 
Wagner, J. (1996). Firm size and job quality: A survey of the evidence from Germany. Small Business Economics, 9, 411-425.

Wanrooy, B.V., Bewley, H., Bryson, A., Forth, J., Freeth, S., Stokes, L., \& Wood, S. (2013). The 2011 workplace employment relations study: First findings. Available

at: https://www.gov.uk/government/uploads/system/ uploads/attachment_data/file/175479/13-535-the2011-workplace-employment-relations-study-firstfindings 1.pdf. Retrieved at 3 July, 2013.

Wilkes, L., Beale, B., Hall, E., Rees, E., Watts, B., \& Benne, C. (1998). Community nurses' descriptions of stress when caring in the home. International Journal of Palliative Nursing, 4, 14-20.
Wooldridge, J. (2002). Econometric analysis of cross section and panel data. Cambridge: MIT Press.

Xu, W., Zhao, Y., Guo, L., Guo, Y., \& Gao, W. (2009). Job stress and coronary heart disease: A case-control study using a Chinese population. Journal of Occupational Health, 51, 107-113.

\section{Appendix I}

Table A1. An Organizational Stress Screening Tool factor structure

\begin{tabular}{ll}
\hline Factor & \multicolumn{1}{c}{ Descriptions } \\
\hline $\begin{array}{l}\text { Work relationships } \\
\text { Your job }\end{array}$ & $\begin{array}{l}\text { Source of stress relating to the contacts people have at work with their colleagues/managers. } \\
\text { Source of stress relating to the fundamental nature of the job itself. } \\
\text { Control }\end{array}$ \\
$\begin{array}{l}\text { Source of stress relating to workload and time pressure. } \\
\text { Source of stress relating to the amount of control people have over their work. } \\
\text { Resource and communication } \\
\text { Source of stress relating to the level of job security perceived by people. } \\
\text { Source of stress relating to the equipment/source available at work and the effectiveness } \\
\text { of communication in the work. } \\
\text { Source of stress relating to the extent to which the demands of work interfere with people's } \\
\text { personal and home life. }\end{array}$ \\
$\begin{array}{l}\text { The extent to which people feel their organization is committed to them. } \\
\text { Organizational commitment } \\
\text { to the employees }\end{array}$ \\
$\begin{array}{l}\text { Employee commitment } \\
\text { to the organization } \\
\text { Physical health }\end{array}$
\end{tabular}

Table A2. Statistics summary of controlled variables, weighted

\begin{tabular}{lr}
\hline Individual and establishment characteristics & $\%$ \\
\hline Job tenure (base category: less than 1 year) & 12.2 \\
less than 1 year & 11.1 \\
1 year to less than 2 years & 25.4 \\
2 years to less than 5 years & 24.1 \\
5 years to less than 10 years & 27.1 \\
10 years or more & 94.2 \\
Permanent (base category: temporary or fixed term) & 48.5 \\
Female (base category: male) & \\
Age (base category: 16-21 years) & 5.8 \\
$16-21$ years & 18.0 \\
$22-29$ years & 22.3 \\
$30-39$ years & 25.2 \\
$40-49$ years & 20.8 \\
$50-59$ years & 7.8 \\
M0-65 + years & 68.1 \\
Married (base category: otherwise) & 34.9 \\
Children (base category: no children) & 16.1 \\
Caring responsibilities (base category: no responsibilities) & 8.0 \\
Long-term illness (base category: no long-term illness) & 94.6 \\
Academic qualification (base category: no academic qualification) & 36.5 \\
Supervisor responsibilities (base category: no supervisor responsibilities) & \\
Wage (base category: £60-100 per week) & \\
\hline
\end{tabular}


Table A2. (Continued)

\begin{tabular}{lr}
\hline Individual and establishment characteristics & $\%$ \\
\hline$£ 60-100$ per week & 6.5 \\
$£ 101-220$ per week & 14.2 \\
$£ 221-310$ per week & 15.2 \\
$£ 311-430$ per week & 21.3 \\
$£ 431-520$ per week & 11.4 \\
$£ 521-650$ per week & 10.9 \\
$£ 651-820$ per week & 8.6 \\
$£ 821-1050$ per week & 5.1 \\
$£ 1050+$ per week & 6.7 \\
Work conditions changes due to & 62.2 \\
recent recession (base category: no changes) & \\
Organizational supports (formal HR policies) & \\
Adversely affected by recent recession & 0.71 \\
(base category: otherwise) & 91.6
\end{tabular}

${ }^{{ }^{*} \text { Mean is reported for the continuous variable. The Human Resource (HR) variables includes information on the following }}$ management practices: investor in people accreditation, induction programme for new staff, job training, employees' views, formal procedure for dealing with individual grievances, formal procedure for dealing with discipline and dismissals, formal written policy on diversity/equal opportunities, disability scheme, statutory maternity pay, non-pay benefits and presence of a joint committee, which deals with health and safety matters.

Table A3. Estimates of the employees' experience of overall job stress: overall sample

\begin{tabular}{|c|c|c|}
\hline Regression specifications & OLS & Ordered probit regression \\
\hline & Coefficients & Coefficients \\
\hline \multicolumn{3}{|l|}{ Employee level characteristics } \\
\hline \multicolumn{3}{|l|}{ Job tenure (base category: less than 1 year) } \\
\hline \multirow[t]{2}{*}{1 year to less than 2 years } & $0.095^{* * *}$ & $0.179^{* * *}$ \\
\hline & 0.034 & 0.056 \\
\hline \multirow[t]{2}{*}{2 years to less than 5 years } & $0.095^{\star * *}$ & $0.175^{\star * *}$ \\
\hline & 0.028 & 0.048 \\
\hline \multirow[t]{2}{*}{5 years to less than 10 years } & $0.064^{\star \star}$ & $0.133^{\star * *}$ \\
\hline & 0.03 & 0.05 \\
\hline \multirow[t]{2}{*}{10 years or more } & $0.067^{\star *}$ & $0.136^{* * *}$ \\
\hline & 0.031 & 0.051 \\
\hline \multirow[t]{2}{*}{ Permanent (base category: temporary or fixed term) } & 0.023 & 0.036 \\
\hline & 0.034 & 0.058 \\
\hline \multirow{2}{*}{ Female (base category: male) } & 0.006 & 0.016 \\
\hline & 0.019 & 0.029 \\
\hline \multicolumn{3}{|l|}{ Age (base category: $16-21$ years) } \\
\hline \multirow{2}{*}{$22-29$ years } & $0.103^{* *}$ & $0.195^{\star * *}$ \\
\hline & 0.04 & 0.073 \\
\hline \multirow[t]{2}{*}{$30-39$ years } & $0.098^{* *}$ & $0.148^{* *}$ \\
\hline & 0.042 & 0.075 \\
\hline \multirow[t]{2}{*}{$40-49$ years } & -0.009 & -0.017 \\
\hline & 0.042 & 0.076 \\
\hline \multirow[t]{2}{*}{$50-59$ years } & -0.063 & -0.081 \\
\hline & 0.042 & 0.077 \\
\hline \multirow[t]{2}{*}{$60-65+$ years } & $-0.187^{\star * *}$ & $-0.271^{\star * *}$ \\
\hline & 0.047 & 0.087 \\
\hline Married (base category: otherwise) & $-0.046^{* *}$ & $-0.060^{\star *}$ \\
\hline
\end{tabular}


Table A3. (Continued)

\begin{tabular}{|c|c|c|}
\hline Regression specifications & OLS & Ordered probit regression \\
\hline & 0.018 & 0.029 \\
\hline \multirow[t]{2}{*}{ Children (base category: no children) } & $-0.035^{\star}$ & -0.05 \\
\hline & 0.021 & 0.032 \\
\hline \multirow[t]{2}{*}{ Caring responsibilities (base category: no responsibilities) } & 0.037 & $0.072^{*}$ \\
\hline & 0.024 & 0.039 \\
\hline \multirow[t]{2}{*}{ Long-term illness (base category: no long-term illness) } & $0.252^{* * *}$ & $0.305^{\star * *}$ \\
\hline & 0.034 & 0.049 \\
\hline \multirow[t]{2}{*}{ Academic qualification (base category: no academic qualification) } & 0.008 & 0.065 \\
\hline & 0.043 & 0.072 \\
\hline \multirow[t]{2}{*}{ Supervisor responsibilities (base category: no responsibility) } & $0.065^{\star * *}$ & $0.135^{\star * \star}$ \\
\hline & 0.019 & 0.031 \\
\hline \multicolumn{3}{|l|}{ Wage (base category: $\mathfrak{E} 60-100$ per week) } \\
\hline \multirow[t]{2}{*}{$£ 101-220$ per week } & $0.133^{* * *}$ & $0.282^{* * *}$ \\
\hline & 0.037 & 0.07 \\
\hline \multirow[t]{2}{*}{$£ 221-310$ per week } & $0.165^{\star * *}$ & $0.341^{\star * *}$ \\
\hline & 0.039 & 0.071 \\
\hline \multirow[t]{2}{*}{$\mathfrak{E} 311-430$ per week } & $0.183^{* * *}$ & $0.393^{* * *}$ \\
\hline & 0.04 & 0.073 \\
\hline \multirow[t]{2}{*}{$£ 431-520$ per week } & $0.167^{\star * *}$ & $0.365^{\star * *}$ \\
\hline & 0.043 & 0.077 \\
\hline \multirow[t]{2}{*}{$£ 521-650$ per week } & $0.193^{\star * *}$ & $0.408^{\star * *}$ \\
\hline & 0.045 & 0.081 \\
\hline \multirow[t]{2}{*}{$\mathfrak{E} 651-820$ per week } & $0.215^{\star * *}$ & $0.449^{\star * *}$ \\
\hline & 0.048 & 0.082 \\
\hline \multirow[t]{2}{*}{$\mathfrak{E} 821-1050$ per week } & $0.241^{\star * *}$ & $0.522^{* * *}$ \\
\hline & 0.05 & 0.086 \\
\hline \multirow[t]{2}{*}{$£ 1050+$ per week } & $0.318^{\star * *}$ & $0.625^{\star * *}$ \\
\hline & 0.051 & 0.09 \\
\hline \multirow[t]{2}{*}{ Work conditions changes due to recent recession (base category: no changes) } & $0.084^{* * *}$ & $0.146^{\star * *}$ \\
\hline & 0.017 & 0.029 \\
\hline \multicolumn{3}{|l|}{ Workplace level characteristics } \\
\hline \multirow[t]{2}{*}{ Organizational supports (formal HR policies) } & $-0.153^{\star * *}$ & $-0.301^{* * *}$ \\
\hline & 0.058 & 0.095 \\
\hline \multirow[t]{2}{*}{ Adversely affected by recent recession (base category: otherwise) } & -0.003 & -0.031 \\
\hline & 0.034 & 0.056 \\
\hline Log likelihood & - & -7699.12 \\
\hline$\chi^{2}$ (Degrees of freedom) & - & $2434.24(37)$ \\
\hline Adjusted $R^{2}$ & 0.34 & - \\
\hline Observations & 7182 & 7182 \\
\hline
\end{tabular}

Standard errors are reported beneath parameter estimates (in italic).

OLS: ordinary least squares.

${ }^{*} p<0.10$.

${ }^{* *} p<0.05$.

${ }^{* * *} p<0.01$. 